Anna Różańska

Dorota Romaniszyn

Agnieszka Chmielarczyk

Małgorzata Bulanda

\title{
BACTERIA CONTAMINATION OF TOUCH SURFACES IN POLISH HOSPITAL WARDS
}

\author{
Jagiellonian University Medical College, Kraków, Poland \\ Chair of Microbiology
}

\begin{abstract}
Background: The objective of the study has been to evaluate the pathogenic bacteria contamination of touch surfaces in hospital wards. Material and Methods: Samples were taken from frequently touched surfaces in the hospital environment in 13 units of various types. Culturing was carried out on solid blood agar and in growth broth (tryptic soy broth - TSB). Species identification was performed using the analytical profile index (API) biochemical testing and confirmed with matrix assisted laser desorption ionization time-flight mass spectrometry (MALDI-TOF-MS) system. Results: The total of 161 samples were taken for the study. Fifty-two of them, after $24 \mathrm{~h}$ of culture on a solid medium, demonstrated bacterial growth and further 60 samples had growth after prior multiplication in TSB. Overall, $69.6 \%$ of samples exhibited growth of 19 bacterial species. Pathogenic species - representing indicator organisms of efficiency of hospital cleaning - was demonstrated by $21.4 \%$ of samples. Among them Acinetobacter spp., Enterocococci spp. and Staphylococcus aureus were identified. Coagulase-negative staphylococci (CNS) were predominant. The proportion of various groups of bacteria significantly varied in respective hospitals, and in various types of wards. Disturbing observation is a large proportion of resistance of isolated CNS strains as a potential reservoir of resistance genes. Conclusions: The results show that touch surfaces in hospital units are contaminated by both potentially pathogenic and pathogenic bacterial species. In connection with the reported, also in Poland, frequent omission or incorrect execution of hand hygiene by hospital staff, and probably patients, touch surfaces still constitute important reservoir of pathogenic bacteria. Improving hand hygiene compliance of health-care workers with recommendations is necessary for increasing biological safety of hospital environment. Med Pr 2017;68(4):459-467
\end{abstract}

Key words: patient safety, hand hygiene, occupational exposure to biological agents, safety and health at work, touch surfaces, hospital hygiene

Corresponding author: Anna Różańska, Jagiellonian University Medical College, Chair of Microbiology,

Czysta 18, 31-121 Kraków, Poland, e-mail: rozanska@ifb.pl

Received: November 15, 2016, accepted: March 7, 2017

\section{INTRODUCTION}

Hospital employees and patients, due to staying in a specific environment, i.e., the hospital environment, are susceptible to various, potentially harmful, physical, chemical and biological agents. Employee exposure to these agents may result in developing diseases, which in this case are classified as occupational diseases, and in the case of patients the effects of exposure are called adverse effects.

According to the reports of the Nofer Institute of Occupational Medicine, Łódź, Poland, in recent years in Poland, health care employees have reported the greatest number of occupational diseases associated with biological factors $[1,2]$. A review of the literature also indicates that the most common adverse events in the case of patients are health care-associated infections [3]. Biological agents that cause occupational diseases among the personnel are mainly viruses transmitted through blood and tubercle bacilli $[1,2]$. As regards infections among patients, bacterial agents are predominant.

In order to prevent infection in the case of hospital staff and patients, various procedures of broadly defined hospital hygiene are applied, such as decontamination of equipment and surfaces, hand hygiene, the use of personal protective equipment $[4,5]$. However, their effectiveness is limited due to mistakes arising from their improper use, and sometimes failure to perform them, despite existing recommendations.

Funding: the study was conducted in the framework of a project financed by the National Research and Development Centre, No. PBS3/ A9/32/2015 entitled "Studies on the antimicrobial properties of copper and copper alloy for applications as a touch surfaces in health care." Project manager: prof. Małgorzata Bulanda. 
This primarily concerns the hand hygiene procedure but also the use of barrier personal protective equipment [6-8]. Garus-Pakowska [6,7], in an observational study, found that in the situation prior to contact with the patient, only $16.8 \%$ of doctors and $4.7 \%$ of nurses performed hand hygiene according to the recommendations, and after contact these proportions were $53.1 \%$ and $25.3 \%$, respectively.

In Poland, there is the official regulation on hazardous biological agents in work environment, including healthcare sector [9]. According to this regulation biological agents are classified into 4 groups, depending on virulence, and treatment and prevention options.

The hands of the staff are one of the major routes of transmission of microorganisms. Consequently, the inanimate hospital environment may be contaminated with various kinds of microbes, especially potentially pathogenic bacteria. Transmission of infections through contact in healthcare settings is still - despite the use of sanitary regime - very frequent. This problem becomes particularly important in the case of appearance of multiresistant microorganisms - as methicillin-resistant Staphylococcus, vancomycin-resistant enterococci and non-fermenting rods [10-13] in a hospital environment. This applies, in particular, to touch surfaces in hospital rooms. The quantitative level of touch surfaces contamination in hospital wards differs depending on the type of surfaces, type of wards or hygienic regimen in a specific unit $[14,15]$. The same applies to qualitative differences (bacterial, fungal or viral species). Regarding Polish hospitals environment, data on the level and qualitative characteristics of bacterial touch surfaces contamination is extremely rare. This has been the main reason of performing this study, which complements data necessary for description of the epidemiological situation in Polish hospitals and the effectiveness of the procedures for decontamination and cleaning.

The objective of this study has been to evaluate potentially pathogenic bacteria contamination of touch surfaces in various types of selected hospitals wards with special emphasis on the species characteristics of bacteria isolated and to analyze whether there are significant differences among various units.

\section{MATERIAL AND METHODS}

\section{Study hospitals and type of indoor surfaces}

The study was conducted in the period from June to September 2015 in 13 departments of 3 hospitals of varied sizes and types in the Małopolska Province, Po- land. Hospital No. 1 is small (130 beds) and primarily surgical. Hospital No. 2 is big (568 beds), highly specialized, with clinical departments. Hospital No. 3 is a multiprofile provincial hospital (669 beds) (Table 1). Among the departments, from which environmental swabs were taken, there were: 3 intensive care units (23\%), 5 surgical wards (38\%), and 5 non-surgical departments (38\%). Detailed information on the type of wards and numbers of taken samples in each ward is presented in the Table 1 . The common denominator for all hospitals was the fact that the infection control programs in these entities meet the highest requirements in terms of surveillance of infections, which is confirmed by quality certificates. Therefore, it may be assumed that decontamination procedures for hospital rooms are followed in these institutions.

Environmental samples were taken from the following surfaces: the worktop in sickroom, bedside table top, drip stand, bed frame, soap dispenser, disinfecting fluid dispenser, light switch, ventilator monitor, mobile phone, department landline phone receiver, computer keyboard, dressing (or surgical) trolley worktop, door handle, protective gloves container, tissue pack-

Table 1. Study hospital characteristics and samples taken from contact surfaces in various types of wards in Poland, 2015

\begin{tabular}{lcc}
\hline \multicolumn{1}{c}{ Hospital and wards } & $\begin{array}{c}\text { Beds } \\
{[\mathrm{n}]}\end{array}$ & $\begin{array}{c}\text { Samples taken } \\
{[\mathrm{n}(\%)]}\end{array}$ \\
\hline $\begin{array}{l}\text { 1. Specialized } \\
\text { surgical 1 }\end{array}$ & 130 & $38\left(23.60^{\star}\right)$ \\
ICU 1 & 568 & $14(36.80)$ \\
2. Highly specialized, & & $24(63.20)$ \\
with clinical departments & & $67\left(41.60^{*}\right)$ \\
ICU 2 & & $12(17.90)$ \\
medical 1 & & $10(14.90)$ \\
surgical 2 & & $10(14.90)$ \\
surgical 3 & & $7(10.40)$ \\
ICU 3 & & $13(19.40)$ \\
medical 2 & $7(10.40)$ \\
surgical 4 & & $8(11.90)$ \\
3. Multiprofile provincial & & $56\left(34.78^{*}\right)$ \\
medical 3 & & $16(28.60)$ \\
surgical 5 & & $12(21.40)$ \\
medical 4 & & $15(26.80)$ \\
ICU 4 & 669 & $13(23.20)$ \\
\hline
\end{tabular}

ICU - intensive care unit.

* Distribution between hospitals. 
age. Detailed information on the number of samples taken from specific surfaces is presented in the Table 2. A substantial part of the tested surface was not flat, so swab method was chosen for the study purposes.

Surface swabs specimens were taken in the morning (7 a.m.), before the start of standard unit operations. Swabs were taken from surfaces of approx. $10 \mathrm{~cm}^{2}$ by means of cotton tipped applicators pre-moistened with sterile saline and placed into the Amies transport medium (Deltalab, Spain) for the purpose of the delivery to the laboratory (transport in the temperature about $20-25^{\circ} \mathrm{C}$ ).

The specimens were cultured on solid medium Columbia Agar with 5\% Sheep Blood (Becton-Dickinson, New Jersey, USA) and after seeding the swabs were placed into Trypticasein Soy Broth (TSB) (BIOCORP, Warszawa, Poland) for $24 \mathrm{~h}$ at the temperature of $37^{\circ} \mathrm{C}$. If the growth on solid medium was obtained on the blood agar (after $24 \mathrm{~h}$ of incubation), the result was evaluated semi-quantitatively according to the following criteria: abundant growth of over 10 colonies on the plate, moderately abundant growth of between 6-10 colonies on the plate and scarce growth of 1-5 colonies on the plate. Samples which exhibited growth only in TSB were once plated on blood agar following multiplication and cul-

Table 2. Samples taken from various types of contact surfaces in the studied hospitals in Poland, 2015

\begin{tabular}{lc}
\hline \multicolumn{1}{c}{ Surface } & $\begin{array}{c}\text { Samples taken } \\
(\mathrm{N}=161) \\
{[\mathrm{n}(\%)]}\end{array}$ \\
\hline Worktop in sickroom & $17(10.6)$ \\
Bedside table top & $13(8.1)$ \\
Drip stand & $13(8.1)$ \\
Bed frame & $17(10.6)$ \\
Soap dispenser & $16(9.9)$ \\
Disinfecting fluid dispenser & $15(9.3)$ \\
Light switch & $15(9.3)$ \\
Respirator monitor & $9(5.6)$ \\
Mobile phone & $10(6.2)$ \\
Department landline phone receiver & $11(6.8)$ \\
Computer keyboard & $11(6.8)$ \\
Dressing (or surgical) trolley worktop & $7(4.3)$ \\
Door handle & $3(1.9)$ \\
Protective gloves container & $2(1.2)$ \\
Tissue package & $2(1.2)$ \\
\hline
\end{tabular}

tured for next $24 \mathrm{~h}$ ( $48 \mathrm{~h}$ in total) at the temperature of $37^{\circ} \mathrm{C}$.

Since the area of swabs on selected surfaces was not precisely controlled and for most samples bacterial growth was obtained after previous multiplication in TSB, the results of growth on blood agar were only registered in a semi-quantitative manner.

\section{Bacterial species identification}

Species identification was carried out using the analytical profile index (API) biochemical tests (API Staph, API Strep, API NE, API 20E (bioMérieux, Marcy-l' Étoile, France)) and a modern method of matrix-assisted laser desorption ionization time-flight massspectroscopy (MALDI-TOF-MS) (Microflex LT, Bruker Daltonics, Coventry, United Kingdom). The resulting spectra for each culture was analyzed by MALDI-Biotyper 2.0 software (Bruker Daltonics, Coventry, United Kingdom). Briefly, the sample was mixed with a matrix on a conductive metal plate. After crystallization of the matrix and microbial material, the metal plate was introduced in the mass spectrometer. The desorbed and ionized molecules were accelerated through an electrostatic field and ejected through a metal flight tube subjected to vacuum until they reached a detector, Mass spectrum was compared with a database for the identification at the species or genus level. The MALDITOF is currently the most modern technique to identify the species of bacteria using the culture method. The advantages of this method include standardized working protocol, fast and precise identification, the low number of false identification in contrast to biochemical system. The disadvantage may be a relatively high cost [16].

Characteristics of isolated strains for resistance to drugs most commonly used in infections of specific etiology were additionally performed. Drug resistance, methicillin-resistant Staphylococcus aureus (MRSA) phenotype and macrolide-lincosamide-streptogramin B (MLSB) resistance phenotype was determined in accordance with the recommendations of the European Committee on Antimicrobial Susceptibility Testing (EUCAST) guidelines [17], using the disk diffusion method.

\section{Statistical analyzing}

Two options of classification of bacteria isolated from environmental swabs were tested. As a criterion of the first category, isolated bacterial strains were assigned to 2 groups: potentially pathogenic bacterial vs. other bacteria. Potentially pathogenic bacteria were species 
isolated in infections in human (staphylococci, streptococci, Gram-negative bacilli). Other bacteria were the bacteria typical for the environment (e.g., Bacillus spp., Micrococcus spp.), incidentally isolated in infections. The second category of classification arose from the classification according to the number of specific bacteria among potentially pathogenic bacteria, such as: coagulase-negative staphylococci vs. streptococci vs. other bacteria.

The percentage distribution of the variables and the relationships among them were investigated using the $\mathrm{Chi}^{2}$ test or Fisher exact test - where the expected values were below 5 in at least $20 \%$ of the cells. The statistical package IBM SPSS Statistics v. 23 (IBM Corp) was used for the analysis purposes.

\section{RESULTS}

\section{Positive results of cultures depending on method and characteristics of bacterial species}

The total of 161 samples were taken. In the case of 52 of them, after $24 \mathrm{~h}$ of culture on solid medium, there was

Table 3. Positive results of bacterial culture in the studied hospitals in Poland, 2015, depending on types of culture

\begin{tabular}{|c|c|c|c|}
\hline \multirow[b]{2}{*}{$\begin{array}{l}\text { Hospitals } \\
\text { and wards }\end{array}$} & \multicolumn{2}{|c|}{$\begin{array}{l}\text { Positive results } \\
\text { [n }(\%)]\end{array}$} & \\
\hline & $\begin{array}{l}\text { on the blood agar } \\
\text { (after } 24 \mathrm{~h} \\
\text { of culture) }\end{array}$ & $\begin{array}{l}\text { on the blood agar } \\
\text { after prior bacterial } \\
\text { multiplication } \\
\text { in TSB } \\
\text { (after } 48 \mathrm{~h} \\
\text { of culture in total) }\end{array}$ & $\mathrm{p}$ \\
\hline
\end{tabular}

\begin{tabular}{lrrr}
\hline Hospital & & & 0.817 \\
No. 1 & $8(40.0)$ & $12(60.0)$ & \\
No. 2 & $21(47.7)$ & $23(52.3)$ \\
No. 3 & $23(47.9)$ & $25(52.1)$
\end{tabular}

Wards

ICU vs. others

0.908

$\begin{array}{lll}\text { ICU } & 17(47.2) & 19(52.8) \\ \text { others } & 35(46.1) & 41(53.9)\end{array}$

surgical vs. others

0.097

\begin{tabular}{llll} 
surgical & $11(32.4)$ & $23(67.6)$ & \\
ICU & $17(47.2)$ & $19(52.8)$ & \\
medical & $24(57.1)$ & $18(42.9)$ & \\
Total & $52(46.4)$ & $60(53.6)$ & n.a. \\
\hline
\end{tabular}

ICU - intensive care unit, TSB - triptic soy broth.

n.a. - not applicable.

* Isolation of any bacterial species. growth of potentially pathogenic bacteria, and in the case of 60 samples bacterial growth was obtained after prior multiplication in liquid medium and culture on solid medium (total time of receiving positive results $-48 \mathrm{~h}$ ) (Table 3). A half of the samples which yielded a positive result of culture on solid medium (48.1\%) demonstrated moderate growth (Table 4 ). The number of positive cultures obtained in individual hospitals and the type of growth observed on solid medium after $24 \mathrm{~h}$ of culture did not show statistically significant differences (Table 4). Statistically significant differences were observed in terms of the type of growth (abundant, moderately abundant, scarce) depending on the type of the department, i.e., intensive care units vs. others (Table 4). The proportion of positive cultures observed at sight on the blood agar and after prior multiplication in TSB exhibited no disparities for various types of units (Table 3 ).

In total, $69.6 \%$ of samples had growth of 19 different potentially pathogenic bacterial species, which were: Acinetobacter pittii, A. baumannii, Enterococcus faecalis, E. faecium, E. gallinarum, Lactococcus lactis, Staphylococcus aureus, S. capitis, S. caprae, S. epidermidis, S. haemolyticus, S. hominis, S. pettenkoferi,

Table 4. Growth of bacteria isolated on the blood agar (after $24 \mathrm{~h}$ of incubation) from samples taken from contact surfaces in the studied hospitals in Poland, 2015

\begin{tabular}{|c|c|c|c|c|}
\hline \multirow{2}{*}{$\begin{array}{l}\text { Hospitals } \\
\text { and wards }\end{array}$} & \multicolumn{3}{|c|}{$\begin{array}{c}\text { Bacteria growth } \\
{[\mathrm{n}(\%)]}\end{array}$} & \multirow{2}{*}{$\mathrm{p}$} \\
\hline & abundant $^{*}$ & $\operatorname{scarce}^{* *}$ & $\begin{array}{l}\text { moderately } \\
\text { abundant }\end{array}$ & \\
\hline Hospital & & & & 0.762 \\
\hline No. 1 & $1(12.5)$ & $2(25.0)$ & $5(62.5)$ & \\
\hline No. 2 & $6(28.6)$ & $4(19.0)$ & $11(52.4)$ & \\
\hline No. 3 & $8(34.8)$ & $6(26.1)$ & $9(39.1)$ & \\
\hline \multicolumn{5}{|l|}{ Wards } \\
\hline ICU vs. others & & & & 0.023 \\
\hline $\mathrm{ICU}$ & $1(5.9)$ & $4(23.5)$ & $12(70.6)$ & \\
\hline others & $14(40.0)$ & $8(22.9)$ & $13(37.1)$ & \\
\hline surgical vs. others & & & & 0.004 \\
\hline surgical & $4(36.4)$ & $0(0.0)$ & $7(63.6)$ & \\
\hline ICU & $1(5.9)$ & $4(23.5)$ & $12(70.6)$ & \\
\hline medical & $10(41.7)$ & $8(33.3)$ & $6(25.0)$ & \\
\hline Total & $15(28.8)$ & $12(23.1)$ & $25(28.8)$ & n.a. \\
\hline
\end{tabular}

Abbreviations as in Table 3 .

${ }^{*}$ More than 10 colonies per plate, ${ }^{* *} 1-5$ colonies per plate, ${ }^{* *} 6-10$ colonies per plate. 
S. simulans, S. warneri, Streptococcus parasanguinis, S. gordonii, S. mitis, and S. oralis. Taking into account the morphology of individual species and their virulence, the isolated microbes were as follows: coagulasenegative staphylococci (85.7\%), Staphylococcus aureus (2.7\%), streptococci (including E. faecalis) (8.9\%), Gram-negative bacilli (1.8\%) and others (0.9\%). For the final identification of bacterial species the MALDI-TOF method was chosen. There were the differences in the species identification performed by the API and MALDI in the case of 19 strains (20\%). The most common species identified differently were: S. capitis (API) and S. pettenkoferi (MALDI), S. aureus (API) and S. haemolyticus or S. simulans (MALDI), S. hominis (API) and S. warneri (MALDI), S. epidermidis (API) and S. warneri (MALDI).

\section{Analysis of proportion}

\section{of different bacteria groups in study wards}

Due to the size of these groups, 3 groups were distinguished for the purpose of the analysis of differences in surface contamination among units and hospitals: coagulase-negative staphylococci, streptococci and the remaining species. In all hospitals covered by the study, coagulase-negative staphylococci were most numerous. Their proportion ranged from $77.3 \%$ in hospital No. 2 to $95.8 \%$ in hospital No. 3 and these differences were statistically significant $(\mathrm{p}=0.036)$ (Table 5). More than a half $-57.1 \%$ of the analyzed strains of Staphylococcus showed resistance to methicillin, which was synonymous with resistance to all $\beta$-lactam antibiotics. Resistance to gentamicin showed $42.9 \%$, to ciprofloxacin $-37.8 \%$, and MLS B phenotype presented $50 \%$ isolates. Statistically significant differences as regards the frequency and the type of bacteria isolated were also confirmed in the variant considering a negative result, a positive result with isolation options of only potentially pathogenic bacteria, other bacteria (species characteristic of the environment, e.g., Bacillus spp.) and mixed growth, i.e., both environmental bacteria and potential pathogens (Table 6).

Statistically significant differences were observed in the proportion of the respective bacterial groups, divided into potentially pathogenic bacteria vs. no growth, cultured in the materials collected from different departments, both when the units were categorized according to the scheme intensive care unit (ICU)/ non-ICU, as well as ICU/non-surgical/surgical (Table 6). In intensive care units, potentially pathogenic bacteria were isolated from $58.1 \%$ of samples ( 29 of 55 ), while in
Table 5. Bacteria of different groups in samples taken from contact surfaces in the studied hospitals in Poland, 2015

\begin{tabular}{lllll}
\hline \multirow{2}{*}{$\begin{array}{c}\text { Hospitals } \\
\text { and wards }\end{array}$} & \multicolumn{3}{c}{$\begin{array}{c}\text { Isolated bacteria } \\
\text { [n (\%)] }\end{array}$} \\
\cline { 2 - 3 } Hospital & CNS & streptococci & others \\
No. 1 & $16(80.0)$ & $3(15.0)$ & $1(5.0)$ & 0.036 \\
No. 2 & $34(77.3)$ & $5(11.4)$ & $5(11.4)$ & \\
No. 3 & $46(95.8)$ & $2(4.2)$ & $0(0.0)$ & \\
Wards & & & & \\
ICU vs. others & & & & \\
ICU & $30(83.3)$ & $4(11.1)$ & $2(5.6)$ & \\
others & $66(86.8)$ & $6(7.9)$ & $4(5.3)$ & \\
surgical vs. others & & & & \\
surgical & $28(82.4)$ & $3(8.8)$ & $3(8.8)$ & \\
ICU & $30(83.3)$ & $4(11.1)$ & $2(5.6)$ & \\
medical & $38(90.5)$ & $3(7.1)$ & $1(2.4)$ & \\
\hline
\end{tabular}

CNS - coagulase-negative streptococci.

Other abbreviations as in Table 3.

other units this percentage was $76.8 \%$ (68 of 91). When distinguishing between surgical and non-surgical units other than ICU, pathogenic bacteria were most frequently isolated from non-surgical units $-87.5 \%$. No significant differences were found in the proportions of individual groups of potentially pathogenic bacteria (coagulase-negative staphylococci (CNS) vs. streptococci vs. the remaining species) isolated from the materials taken from units of various types (Table 5).

\section{DISCUSSION}

The majority of bacteria cultured from materials taken from touch surfaces of hospital units were coagulasenegative staphylococci. However, Gram-negative bacilli (E. coli, Acinetobacter spp.), Enterococcus faecalis and Staphylococcus aureus which represented "indicator" organisms of hospital cleaning effectiveness [18,19] were also grown. These microorganisms caused various infections both in hospitalized patients and the general population. According to the Polish Minister of Health's regulation on biological agents which classifies the harmful biological agents into 4 groups based on infective properties (the level of risk of infection) for people with standard immune systems [9], bacteria from the species Stapylococcus aureus, genera Streptococcus spp., Enterococcus spp. and the species E. coli 
Table 6. Types of bacteria isolated from samples taken from contact surfaces in the studied hospitals in Poland, 2015

\begin{tabular}{|c|c|c|c|c|c|}
\hline \multirow{2}{*}{$\begin{array}{l}\text { Hospitals } \\
\text { and wards }\end{array}$} & \multicolumn{4}{|c|}{$\begin{array}{l}\text { Isolated bacteria } \\
{[\mathrm{n}(\%)]}\end{array}$} & \multirow{2}{*}{$\mathrm{p}$} \\
\hline & none & $\begin{array}{l}\text { potentially pathogenic } \\
\text { (A) }\end{array}$ & $\begin{array}{l}\text { others }{ }^{* *} \\
\text { (B) }\end{array}$ & $\begin{array}{c}\text { mixed } \\
\text { (A and } B \text { in } 1 \text { sample) }\end{array}$ & \\
\hline Hospital & & & & & 0.001 \\
\hline No. 1 & $16(42.1)$ & $16(42.1)$ & $2(5.3)$ & $4(10.5)$ & \\
\hline No. 2 & $12(17.9)$ & $37(55.2)$ & $11(16.4)$ & $7(10.4)$ & \\
\hline No. 3 & $5(8.9)$ & $44(78.6)$ & $3(5.4)$ & $4(7.1)$ & \\
\hline \multicolumn{6}{|l|}{ Wards } \\
\hline ICU vs. others & & & & & 0.047 \\
\hline ICU & $18(29.0)$ & $29(46.8)$ & $8(12.9)$ & $7(11.3)$ & \\
\hline others & $15(15.2)$ & $68(68.7)$ & $8(8.1)$ & $8(8.1)$ & \\
\hline surgical vs. others & & & & & 0.022 \\
\hline surgical & $12(23.5)$ & $31(60.8)$ & $5(9.8)$ & $3(5.9)$ & \\
\hline ICU & $18(29.0)$ & $29(46.8)$ & $8(12.9)$ & $7(11.3)$ & \\
\hline medical & $3(6.3)$ & $37(77.1)$ & $3(6.3)$ & $5(10.4)$ & \\
\hline Total & $33(20.5)$ & $97(60.3)$ & $16(9.9)$ & $15(9.3)$ & \\
\hline
\end{tabular}

Abbreviations as in Table 3 .

* Staphylococci, streptococci, Gram-negative bacilli.

** Bacteria typical for the environment, e.g., Bacillus spp., Micrococcus spp.

are included into risk group 2. This group encompasses factors, which may cause disease in people, may be dangerous for workers, but their spread in the human population is unlikely and they may generally be defeated with efficient prophylaxis and treatment.

Considering the study results - by Garus-Pakowska cited above - on compliance with hand hygiene of medical staff in dealing with patients, and another one taking into account the correct use of protective gloves (personal protective equipment) [6-8], or other authors $[20,21]$ it may be stated that hospital staff often disregard the procedures aimed at protecting against harmful biological agents. Consequently, the hospital environment is not a safe work environment, and in particular it is not a microbiologically safe environment for patients. Promoting appropriate behavior and conduct among hospital employees still remains a challenge for employers. It is an even greater challenge for specialists in the field of infection control, who are burdened with the responsibility of educating the personnel on preventing the spread of infections.

By analyzing the results obtained in this study, one should bear in mind that materials for testing were taken in the morning, before normal operation of the departments; therefore, it may be assumed that con- tamination of touch surfaces was smaller than during the work day, when most procedures of diagnosis and treatment were conducted and when the personnel had contact with patients.

In the source literature, one may find many studies devoted to survival/persistence of various bacterial species in the inanimate environment, and the period of survival expressed in terms of days varies within a broad range. For Acinetobacte spp. it may be from 3 days to 5 months, for $E$. coli - from $1.5 \mathrm{~h}$ to over 30 months, for Enterococcus spp. - from 5 days to 4 months, and for $S$. aureus (including MRSA) from 7 days to 7 months [22].

All hospitals, in which the samples were taken from, had had long-standing traditions of reliable infection control and had implemented quality management system. Despite those facts, apart from bacteria representing typical representatives of the normal skin flora (in practice, not representing a threat to staff, but only to some patients), over $1 / 5$ (21.4\%) of positive cultures had growth of species included in risk group 2 [9] (or "indicator" microorganism for proper hospital cleaning). Specifically, Acinetobacter spp. and enterococci, species representing bacteria causing invasive infections in Polish hospitals [23], were isolated from such surfaces as 
a bed frame and light switch. This observation confirms incidence of negligence of hand hygiene procedures in study wards. What is important, samples from the environment in this study were taken early in the morning, before starting the routine hospital day. During standard work hours, when direct contacts of various kinds are most common, a significantly higher contamination of touch surfaces may be expected. It may concern especially the isolation of Gram-negative bacilli, which have been rare in our study, contrary to the study of Garcia-Cruz et al. [24] in which this bacteria species were isolated in more than $50 \%$ of samples. But, the study of Garcia-Cruz was performed in the hospital in Mexico City, that may have been the important source of differences.

A positive observation in our study, however, is the fact that the smallest contamination of touch surfaces has been found in intensive care units, which primarily translates into safety of patients in these units. A significantly smaller contamination in ICUs has been observed in terms of both isolation of potentially pathogenic bacteria as well as categorization of isolates taking into account the percentage of bacteria from the groups, which have been distinguished for the purposes of this analysis (the proportion of coagulase-negative staphylococci, streptococci and other bacteria among all isolates).

However, disturbing observation is a large proportion of resistance of isolated CNS strains for most commonly used drugs, oscillating about 50\%. They may play role of environmental reservoir of resistance genes.

In the hospital environment, it is difficult to avoid this type of contamination with bacterial flora of pieces of departmental equipment [25-27]. The duty of hospital managers is to provide access to effective disinfectants and their proper use. As already mentioned, disinfection processes are particularly susceptible to "human error" associated, e.g., with their omission or improper application [28]. The use of copper alloy surfaces may be a complement to standard disinfection. They have proven antimicrobial properties and are used in order to improve safety of patients and personnel. Some hospitals in various countries have already introduced pieces of equipment made of antimicrobial materials. Moreover, results of relatively scarce, hitherto, research have confirmed the decrease in infections of this type in hospital units [29]. Introduction of this type of equipment into hospitals should be preceded by a careful analysis of the situation in a given facility, in departments of various types. As shown by the results of this study, the proportion of different groups of bacteria at individual hospitals has been significantly varied, which, according to the authors, results more from the specificity of these units than from differences in cleaning and decontamination of surfaces.

The limitation of the study is mainly the number of hospitals, from which the test material was obtained, and also, to some extent, the method of taking samples. The number of hospitals determining the number of cultures executed, isolations, and identifications of species was conditioned by our organizational capacity.

The study materials were collected using swabs, which was one of the methods used for taking samples from the environment for microbiological tests $[18,19$, 30,31 . Swabs were taken from surfaces of approx. $10 \mathrm{~cm}^{2}$, which did not allow to carry out strictly quantitative examinations but only a semi-quantitative description of the results. The study of microbiological purity of the surface often employs the imprint method, in which the microorganisms present on the surfaces are imprinted directly on a growth medium, which certainly has an effect on the sensitivity of the assay. In this case, samples were collected, among others, from the following surfaces: the bed frame, phone receiver or door handle/other handles, which significantly limits the application of the imprint method. However, the culture of the collected material in a liquid growth medium was a way to increase the sensitivity of testing. It may be assumed that it was an effective solution since $70 \%$ (60 of 112) of the swabs showed growth of potentially pathogenic bacteria. The method of multiplication bacteria expected in environmental samples was also used by Shimose et. al [32] in the study on Acinetobacter baumannii contamination of air and hospital environmental surfaces.

\section{CONCLUSIONS}

1. Approximately $1 / 5$ of the isolates demonstrated growth of risk group 2 bacteria, which, in the case of negligence concerning hygiene on the part of medical staff, as well as patients, may lead to the development of dangerous diseases.

2. Species composition of hospital touch surface contamination is significantly different in departments of various types - most pathogenic bacteria were isolated in units other than intensive care units, especially in non-invasive units. Disturbing observation is a large proportion of resistance of isolated CNS strains as a potential reservoir of resistance genes. 
3. Improving hand hygiene compliance of healthcare workers with recommendations is necessary for increasing biological safety of hospital environment.

\section{REFERENCES}

1. Szeszenia-Dąbrowska N, Wilczyńska U. Occurrence of occupational diseases in Poland, 2014 and their causative agents. Med Pr. 2016;67(3):327-35, https://doi.org/ 10.13075/mp.5893.00389.

2. Wilczyńska U, Sobala W, Szeszenia-Dąbrowska N. Occupational diseases in Poland, 2012. Med Pr. 2013; 64(3):317-26, https://doi.org/10.13075/mp.5893.2013. 0027.

3. Mittmann N, Koo M, McDonald A, Baker M, Matlow A, Krahn M, et al. The economic burden of patient safety targets in acute care: A systematic review. Drug Healthc Patient Saf. 2012;4:141-65, https://doi.org/10.2147/DHPS. S33288.

4. Książczyk M, Krzyżewska E, Futoma-Kołoch B, BuglaPłoskońska G. Disinfectants - Bacterial cells interactions in the view of hygiene and public health. Postepy Hig Med Dosw. 2015;69:1042-55.

5. Pittet D, Allegranzi B, Sax H, Dharan S, Pessoa-Silva C, Donaldson L. Evidence-based model for hand transmission during patient care and the role of improvement practices. Lancet Infect Dis. 2006;6:641-52, https://doi.org/10.1016/ S1473-3099(06)70600-4.

6. Garus-Pakowska A, Sobala W, Szatko F. Observance of hand washing procedures performed by the medical personnel before patient contact. Part I. Int J Occup Med Environ Health. 2013;26(1):113-21, https://doi.org/10.2478/ s13382-013-0092-4.

7. Garus-Pakowska A, Sobala W, Szatko F. Observance of hand washing procedures performed by the medical personnel after the patient contact. Part II. Int J Occup Med Environ Health. 2013;26(2):257-64, https://doi.org/10.24 78/s13382-013-0094-2.

8. Garus-Pakowska A, Sobala W, Szatko F. The use of protective gloves by medical personnel. Int J Occup Med Environ Health. 2013;26(3):423-9, http://dx.doi.org/10.2478/ s13382-013-0095-1.

9. [Directive of the Health Minister of 22 April 2005 on harmful biological agents in working environment and health's protection of workers exposured on them. J Laws 2005, No. 81, item 716]. Polish.

10. Beggs C, Knibbs LD, Johnson GR, Morawska L. Environmental contamination and hospital-acquired infection: Factors that are easily overlooked. Indoor Air. 2015;25: 462-74, https://doi.org/10.1111/ina.12170.
11. Martinez JA, Ruthazer R, Hansjosten K, Barefoot L, Snydman DR. Role of environmental contamination as a risk factor for acquisition of vancomycin-resistant enterococci in patients treated in a medical intensive care unit of a cancer center. Arch Intern Med. 2003;163(16):1905-12, https:// doi.org/10.1001/archinte.163.16.1905.

12. Ray AJ, Hoyen CK, Taub TF, Donskey CJ. Nosocomial transmission of vancomycin-resistant enterococci from surface. JAMA. 2002;287:1395-6, https://doi.org/10.1001/ jama.287.11.1395.

13. Talon $\mathrm{D}$. The role of the hospital environment in the epidemiology of multi-resistant bacteria. J Hosp Infect. 1999;43:13-7, https://doi.org/10.1053/jhin.1999.0613.

14. Claro T, O’Reilly M, Daniels S, Humphreys H. Surface microbial contamination in hospitals: A pilot study on methods of sampling and the use of proposed microbiologic standards. Am J Infect Contr. 2015;43:1000-2, https://doi. org/10.1016/j.ajic.2015.05.009.

15. Schmidt M, von Dessauer B, Benavente C, Benadof D, Cifuentes $\mathrm{P}$, Elgueta A, et al. Copper surfaces are associated with significantly lower concentrations of bacteria on selected surfaces within a pediatric intensive care unit. Am J Infect Contr. 2015;44(2):1-7, https://doi.org/10.1016/j.ajic.2015.09.008.

16. Urwyler SK, Glaubitz J. Advantage of MALDI-TOF-MS over biochemical-based phenotyping for microbial identification illustrated on industrial applications. Lett Appl Microbiol. 2016;62(2):130-7, https://doi.org/10.11 11/lam.12526.

17. European Committee on Antimicrobial Susceptibility Testing [Internet]. The Committee; 2017 [cited 2016 May 1]. Clinical breakpoints. Available from: http://www.eucast. org/clinical_breakpoints.

18. Al-Hamad A, Maxwell S. How clean is clean? Proposed methods for hospital cleaning assessment. J Hosp Infect. 2008;70:328-34, https://doi.org/10.1016/j.jhin.2008. 08.006 .

19. Dancer SJ. How do we assess hospital cleaning? A proposal for microbiological standards for surface hygiene in hospitals. J Hosp Infect. 2004;56:10-5, https://doi.org/10.1016/ j.jhin.2003.09.017.

20. Różańska A, Wójkowska-Mach J, Bulanda M, Heczko PB. Organzation and scope of surveillance of infections in Polish hospitals. Results of the project PROHIBIT. Przegl Epidemiol. 2014;68:27-32.

21. Różańska A, Wójkowska-Mach J, Bulanda M. Work placements and seniority in health care vs. medical students knowledge of selected hand hygiene procedures. Med Pr. 2016;67(5):623-33, https://doi.org/10.13075/mp.58 93.00440 . 
22. Kramer A, Schwebke I, Kampf G. How long do nosocomial pathogens persist on inanimate surfaces? A systemic review. BMC Infect Dis. 2006;6:130, https://doi.org/10.1186/ 1471-2334-6-130.

23. Talaga K, Bulanda M. Are vancomycin-resistant enterococci a problem in Polish hospitals? Przegl Epidemiol. 2015;69(4):717-22.

24. Garcia-Cruz CP, Aguilar MJN, Arroyo-Helguera OE. Fungal and bacterial contamination on indoor surfaces of a hospital in Mexico. Jundishapur J Microbiol. 2015;5(3): 460-4, https://doi.org/10.5812/jjm.2625.

25. Bures S, Fishbain JT, Uyehara CF, Parker JM, Berg BW. Computer keyboards and faucet handles as reservoirs of nosocomial pathogens in the intensive care unit. Am J Infect Control. 2002;28:465-71, https://doi.org/10.1067/ mic.2000.107267.

26. Hu H, Johani K, Gosbell IB, Jacombs ASW, Almatroudi A, Whiteley GS, et al. Intensive care unit environmental surfaces are contaminated by multidrug-resistant bacteria in biofilms: Combined results of conventional culture, pyrosequencing, scanning electron microscopy, and confocal laser microscopy. J Hosp Infect. 2015;91:35-44, https://doi. org/10.1016/j.jhin.2015.05.016.

27. Lemen SW, Hafner H, Zolldann D, Stanzel S, Lutticken R. Distribution of multi-drug resistant Gram-negative ver- sus Gram-positive bacteria in the hospital inanimate environment. J Hosp Infect. 2004;56:191-7, https://doi. org/10.1016/j.jhin.2003.12.004.

28. Różańska A, Wójkowska-Mach J, Bulanda M, Heczko PB. Infection control in Polish medical wards - Data from the PROHIBIT Project. Przegl Epidemiol. 2015;69(3):495-501.

29. Decraene V, Pratten J, Wilson M. Novel light-activated antimicrobial coatings are effective against surface-deposited Staphylococcus aureus. Curr Microbiol. 2008;57:269-73, https://doi.org/10.1007/s00284-008-9188-7.

30. Lemmen SW, Hafner H, Zolldann D, Amedick G, Lutticken R. Comparison of two sampling methods for the detection of Gram-positive and Gram-negative bacteria in the environment: Moistened swabs versus Rodac plates. Int J Hyg Environ Health. 2001;203:245-8, https://doi. org/10.1078/S1438-4639(04)70035-8.

31. Skóra J, Szponar B, Paściak M, Gutarowska B. [Identification of environmental Actinobacteria representing an occupational health risk]. Postepy Hig Med Dosw. 2013;67: 1222-34. Polish.

32. Shimose LA, Massuda E, Sfer M, Berbel Caban A, Bueno MX, dePascale D, et al. Carbapenem-resistant Acinetobacter baumanii: Concomitant contamination of air and environmental surfaces. Infect Control Hosp Epidemiol. 2016;37:777-81, http://doi.org/10.1017/ice.2016.69.

This work is available in Open Access model and licensed under a Creative Commons Attribution-NonCommercial 3.0 Poland License / Ten utwór jest dostępny w modelu open access na licencji Creative Commons Uznanie autorstwa - Użycie niekomercyjne 3.0 Polska - http://creativecommons.org/ licenses/by-nc/3.0/pl/deed.en. 